\title{
Country-level entrepreneurship: Crowding out the population's need for autonomy
}

\author{
Authors: \\ Colin D. Reddy ${ }^{1}$ \\ Ralph Hamann ${ }^{2}$ \\ Boris Urban ${ }^{3}$ \\ Affiliations: \\ ${ }^{1}$ Department of Business \\ Management, University of \\ Johannesburg, South Africa \\ ${ }^{2}$ Graduate School of Business, \\ University of Cape Town, \\ South Africa \\ ${ }^{3}$ Wits Business School, \\ University of Witwatersrand, \\ South Africa

\section{Correspondence to: \\ Colin Reddy \\ Email: \\ creddy@uj.ac.za \\ Postal address: \\ PO Box 524, Auckland Park \\ 2006, South Africa} \\ Dates: \\ Received: 19 0ct. 2014 \\ Accepted: 13 Apr. 2015 \\ Published: 02 June 2015 \\ How to cite this article: \\ Reddy, C.D., Hamann, R. \& \\ Urban, B., 2015, 'Country- \\ level entrepreneurship: \\ Crowding out the \\ population's need for \\ autonomy', Acta Commercii \\ 15(1), Art. \#292, 8 pages. \\ http://dx.doi.org/10.4102/ \\ ac.v15i1.292

\section{Copyright:} \\ C 2015. The Authors. \\ Licensee: AOSIS \\ OpenJournals. This work is \\ licensed under the Creative \\ Commons Attribution \\ License.
}

Purpose and problem: Governments through their policy support of new and growing enterprises continue to emphasise economic incentives as if most members of the population prioritise material gain. This article argues that high levels of government policy support for new and growing enterprises crowd out the population's need for autonomy when potential entrepreneurs perceive government to be controlling.

Methodology: The researchers constructed a country-level panel data set based on the Global Entrepreneurship Monitor, World Bank Group Entrepreneurship Survey, the World Economic Forum competitiveness reports and the International Monetary Fund database for 44 countries over the period 2000 to 2007. Since we relied on eight years of secondary data, we applied panel analysis to the regressions. We used multiple regression to model the moderating effects of government policy support on the autonomy-entrepreneurship relationship.

Findings: The findings show that government policy support tends to buffer the effect of autonomy on entrepreneurship, lending support to the article's argument.

Implications: This research has tested one of the most important anomalies in economics on entrepreneurship data: that 'crowding out' might reverse the most fundamental economic law, namely that raising economic incentives increases the supply of entrepreneurship.

\section{Introduction}

Within the domain of context-specific beliefs and attitudes towards entrepreneurship, the cultural support lent to those members of the population driven by the need for autonomy is being recognised by entrepreneurship scholars (Albert \& Couture 2013; Carter 2011; Croson \& Minniti 2012; Danziger \& Valency 2006). In particular, it is recognised that there is a subset of entrepreneurs who are prepared to delay some economic incentives to satisfy their need for autonomy (for a theoretical motivation, see Croson \& Minniti 2012).

However, governments through their policy support of new and growing enterprises continue to emphasise economic incentives as if most members of the population prioritise material gain. There are a number of countries where the material needs of the majority - for instance, those in Scandinavia - are likely to have been satisfied and the need for self-realisation takes over (Uhlaner \& Thurik 2007). A focus on economic incentives might risk the 'crowding out' (Frey \& Jegen 2001:3) of the positive effect that the need for autonomy has on country-level entrepreneurship to the extent that overall entrepreneurship levels actually decrease. In fact, evidence exists of support initiatives that lead to a decrease in values such as autonomy and develop dependence amongst entrepreneurs (Albert \& Couture 2013).

Whilst this crowding out effect has been shown at individual, enterprise and community level (see Frey \& Jegen 2001 for examples), it has not been tested at cross-country level and in particular it has not been applied to entrepreneurial activity. We set out to test this hypothesis at a crosscountry level and we argue that government policy support indeed crowds out the population's need for autonomy when potential entrepreneurs perceive government to be controlling.

Economic theory considers largely monetary incentives. In order to test whether economic type government policies crowd out the effect of the need for autonomy on country-level entrepreneurship, we have to combine psychological theory with economic theory and apply them to a country level. We then get to test one of the most important anomalies in economics: that this 'crowding out' might reverse the most fundamental economic law, namely that raising monetary incentives increases the supply of entrepreneurship (Frey \& Jegen 2001). Our research shows that when taken too far to control entrepreneurship outcomes, government policy support can be harmful to those economies requiring high entrepreneurship levels to boost their economic growth. 
We begin by defining the abovementioned concepts more precisely and by deriving an interaction hypothesis from the extant literature. We test this hypothesis empirically and we discuss a theory of the conditions when the need for autonomy will impact positively on entrepreneurship. We conclude with suggestions for further research and we identify some management implications.

\section{Theory and hypotheses Autonomy and entrepreneurship}

We define entrepreneurship as new venture creation (Gartner 1985). Apart from a desire for economic benefits, individuals start new ventures to satisfy their need for autonomy. In order to project this individual level activity to a country level, we rely on an aggregate psychological trait explanation for entrepreneurship: this is based on the idea that if a society contains more individuals with such entrepreneurial values, more individuals will become entrepreneurs (Davidsson 1995; McCrae \& Terracciano 2005; Shane 1993).

Many individuals cherish being their own boss. This need for autonomy is associated with one's desire to gain control of one's own life goals (Breaugh 1999). Such individuals will go as far to value autonomy when making this occupational choice despite the financial outcome being lower when compared to alternatives (Caliendo \& Kritikos 2012). And this might not necessarily imply that they are being irrational or making a decision error (Croson \& Minitti 2012). With the aid of a utility-maximisation model of the individual's decision to exit paid employment, Croson and Minitti (2012) show that new entrepreneurs are willing to accept lower earnings in exchange for autonomy. This is particularly true for those lower-autonomy jobs.

Indeed, empirical studies (Carter et al. 2003; Feldman \& Bolino 2000) also show that many entrepreneurs are driven by the need for autonomy. In Latin America, in the case of self-employed professionals and enterprise owners, the autonomy and flexibility of their occupation seems to be considered an advantage when compared to those in paid employment (Aguilar, García Muñoz \& Moro-Egido 2013).

This need for autonomy is associated with one's intrinsic motivation. Following Deci (1971:105), 'one is said to be intrinsically motivated to perform an activity when one receives no apparent reward except the activity itself'. Intrinsic motivation is an inherent tendency to seek novelty and challenges, extend and exercise one's capacities, explore, and learn (Ryan \& Deci 2000). It describes a natural inclination toward assimilation, mastery, spontaneous interest and exploration that is essential to cognitive and social development. Moreover, it represents a primary source of enjoyment and vitality throughout life (Csikszentmihalyi \& Rathunde 1992).

Intrinsic motivation, according to self-determination theory (Deci \& Ryan 1985), is promoted when the social context within a nation supports psychological needs for competence and autonomy. To the extent that social contexts disallow satisfaction of these psychological needs, they diminish intrinsic motivation, impair natural development and lead to lower entrepreneurship. Moreover, feelings of competence will not enhance intrinsic motivation unless they are accompanied by a sense of autonomy. In other words, individuals must not only experience competence, they must also experience their behaviour as self-determined for intrinsic motivation to manifest (Ryan \& Deci 2000).

\section{Government policy support and entrepreneurship}

Government policy support for entrepreneurship is a formal institution that contributes to the incentive structure for individuals to participate in a country's economy (North 1990). Unlike the need for autonomy, which is associated with intrinsic motivation, government policy support is an external measure - associated with extrinsic motivation designed to motivate an individual into action or effort with the promise of a reward for this action or effort (Carsrud \& Brännback 2011). In the entrepreneurship literature (Kuratko, Hornsby \& Naffziger 1997), incentives are conceptualised as financial rewards, personal wealth acquisition and personal income. Other conceptualisations include relatively intangible things such as status, power and social acceptance, with the more tangible external rewards being money, stock options and other forms of compensation (Carsrud et al. 2009). This largely economic perspective tends to apply to government policy support as well.

Incentives from government policy support arise when it is less burdensome and less costly for individuals to follow the requirements of statutes, constitutions, common laws and other formal regulations, determining governance structure, individual and property rights, contracts and enforcement (North 1990). Regulations, for example, are a diverse set of instruments that governments use to impose requirements on enterprises and citizens. They include laws, formal and informal orders and subordinate rules issued by all levels of government and rules issued by nongovernmental or self-regulatory bodies to which government has delegated regulatory power (OECD 1997). Governments use entrepreneurs as agents to meet their goals of economic growth, since the entrepreneur's effort is a critical component of economic growth (Keuschnigg \& Nielsen 2003; Wennekers \& Thurik 1999). Examples of government policy support, particularly for innovative type entrepreneurship, include intellectual property protections and fiscal incentives (Bhaduri \& Kumar 2011).

However, there is no guarantee that a potential entrepreneur will actually put their time and effort into entrepreneurship. Whilst government perceives the above mentioned as incentives for the entrepreneur, entrepreneurial individuals might not (Laffont \& Tirole 1993). The entrepreneur is a complex individual who does not necessarily respond to external incentives in predictable ways. We argue next that 
this complexity might arise from the way external incentives interact with intrinsic motivation.

\section{Motivation crowding theory and the interaction between autonomy and government policy support}

Motivation crowding theory (Frey 1997) stipulates a systematic interaction between extrinsic and intrinsic motivation, which can be extended to an interaction between government policy support and the need for autonomy. This interaction involves shifts in individual preferences. If a nation contains more individuals with such a need, then we can extrapolate this individual level behaviour to a country level and suggest that some of the variance in country-level entrepreneurship is due to population level autonomy (McCrae \& Terracciano 2005).

When external interventions like government policy support are aligned with intrinsic motivation, motivation crowding theory posits a crowding-in effect. In contrast, when government policy support undermines intrinsic motivation, it has a crowding-out effect. Government policy support, especially those instruments that ease the monetary burden, undermines intrinsic motivation and will tend to have a crowding-out effect (Deci \& Flaste 1995; Deci \& Ryan 1985). According to Frey (1992), this suggests the opposite of the most fundamental economic 'law' stipulating that raising monetary incentives increases supply of effort.

Governments value entrepreneurship as a vehicle for economic growth (Wennekers \& Thurik 1999). Evidence tends to suggest that the policy support designed by governments tends to be largely economic (Hoffman 2007). However, an important motivating factor in the decision to pursue an entrepreneurial career is a desire for independence and control over one's working life (Bradley \& Roberts 2004; Kolvereid 1996). Schjoedt (2009) compares the job satisfaction levels of entrepreneurs and nonfounding managers and finds that autonomy is a significant predictor of job satisfaction amongst entrepreneurs. This of course does not imply that all entrepreneurs settle for lower incomes in comparison to their wage-earning peers (Carter 2011). It simply implies that these individuals consider the intrinsic value of entrepreneurship more important than its extrinsic value.

Following motivation crowding theory, we argue that government policy support crowds out the need for autonomy amongst a nation's entrepreneurial individuals when they perceive government to be controlling. This occurs particularly when support is targeted to new and growing enterprises, which those seeking autonomy might not necessarily aspire to since wealth creation is not a priority. In this instance, both self-determination and self-esteem suffer, and the entrepreneurial individuals respond by remaining in paid employment. When a country contains more individuals with a need for autonomy, more individuals will become entrepreneurs on condition that government policy support

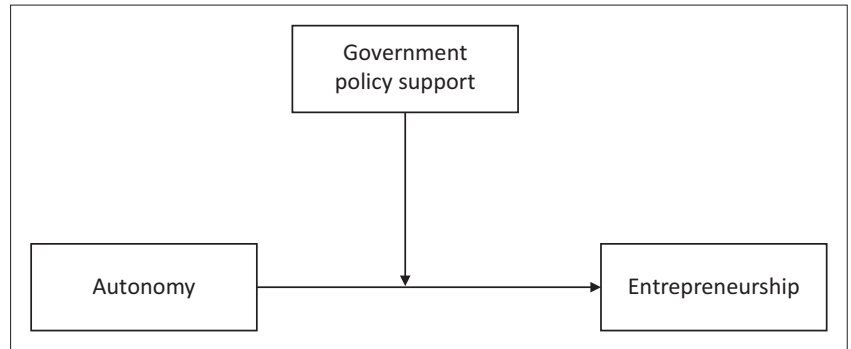

FIGURE 1: Conceptual framework.

is low, since then there is less risk of crowding out intrinsic motivation. Thus, we hypothesise:

Hypothesis 1: Government policy support moderates the relationship between population-level autonomy and entrepreneurship such that autonomy has a positive effect on entrepreneurship when low levels of government policy support are present.

\section{Method}

\section{Sample and data collection}

We constructed a country-level panel data set based on the Global Entrepreneurship Monitor (GEM), World Bank Group Entrepreneurship Survey (WBGES), the World Economic Forum (WEF) competitiveness reports and the International Monetary Fund (IMF) database for 44 countries over the period 2000 to 2007. This resulted in a data set of 178 country-year observations. However, only 118 countryyear observations were used since we made used of lagged variables. There was a minimum of one observation for countries such as Indonesia, Philippines, Israel, Jamaica, Serbia and the Czech Republic. The remaining countries were observed up to a maximum of seven times. Our data set was thus an unbalanced one.

In the case of GEM's national expert survey, each country-year observation was determined by the mean of approximately 36 expert responses. There were thus about 6408 expert responses before an average by country was calculated. There were 48 developing country-year observations and 130 developed country-year observations in the sample. We extracted data for entrepreneurship from the WBGES database regarding new enterprise registrations worldwide, limiting application to formal economies (Acs, Desai \& Klapper 2008; Klapper \& Delgado 2007). Entrepreneurs motivated by an opportunity to grow an enterprise typically register their enterprises (Levie \& Autio 2011).

To assess government policy support and autonomy, we used GEM's national expert survey. GEM uses experts to establish the level of entrepreneurial framework conditions (EFC) in a country. These experts possess a range of backgrounds and knowledge regarding their respective countries. Respondents in each category consist of at least one entrepreneur, two suppliers and one observer such as an academic with expertise on the topic. The expert survey assesses views on institutional environments through standardised questions and validated instruments (De Clercq, Lim \& Oh 2011). 
Aggregation of the survey was based on a mean of 36 responses per country.

Levie and Autio (2008) suggest that EFCs define the rules for entrepreneurship in a given context, supporting North's (1990) depiction of institutions as rules of the game. They also offer a detail review of the GEM EFCs and their theoretical backgrounds, starting with Leibenstein (1968). The EFCs measure conditions for entrepreneurship such as financial support, entrepreneurial content of primary and higher education, business services, market conditions, policy and regulatory conditions, research and development conditions, general entrepreneurial capacity and culture and social images. GEM measures each with multiple-item scales comprising three to seven items. The standard expert survey contains 88 questions, with responses collected on a fivepoint Likert scale, including responses 1 (completely false), 2 (somewhat false), 3 (neither true nor false), 4 (somewhat true) and 5 (completely true).

\section{Measures}

\section{Entrepreneurial activity}

We used the WBGES entry density figure to assess the rate of entrepreneurial activity in a country. The entry density is defined as the number of newly registered limited liability companies per 1000 working-age people (aged 15-64). This variable measures entrepreneurial activity that is based on official business registers and thus provides cross-country data on the number of newly registered enterprises (Acs et al. 2008).

\section{Autonomy}

We used an item from the GEM EFC on cultural norms and values that covers context-specific beliefs about and attitudes towards entrepreneurship (Levie \& Autio 2008). This item assessed whether the national culture emphasises selfsufficiency, autonomy and personal initiative'.

\section{Government policy support}

We used the GEM EFC on government policy. GEM's operationalisation of the government policy EFC does not measure specific policies, but rather focuses on the general prioritisation of entrepreneurship in government economic policy (Levie \& Autio 2008). It indicates the extent of the resources that governments are prepared to commit to new venture creation. This was a three-item scale with an alpha coefficient of 0.84 . The scale assessed whether (1) government policies (e.g. public procurement) consistently favour new enterprises, (2) the support for new and growing enterprises is a high priority for policy at the national government level and (3) the support for new and growing enterprises is a high priority for policy at the local government. Note the emphasis on enterprise growth.

\section{Control variables}

We controlled for the personal capability of the entrepreneur (Wennekers 2006), using the GEM higher education EFC.
We would have controlled for financial and social capital resources if it were not for their high collinearity with the government policy support and the autonomy measure respectively.

A country's economic expansion results in numerous opportunities for entrepreneurship. As a proxy of economic expansion, we controlled for population growth from the previous year. Data were gathered from the World Bank database.

A dummy variable indicated whether a country had a transition economy - in other words, one that transitioned from centrally planned to market-oriented. These included Bosnia and Herzegovina, Croatia, Czech Republic, Hungary, Latvia, Macedonia, Poland, Romania, Russia, Serbia and Slovenia. Bowen and De Clercq (2008) argue that this indicator captures potential for higher growth opportunities arising from structural changes when a country moves towards a market system.

A country's economic development manifests in increased per capita income (Wennekers et al. 2005) and influences entrepreneurship (Acs, Desai \& Hessels 2008; Van Stel, Carree \& Thurik 2005). We used GDP per capita data from the IMF database, after a natural log transformation. Entrepreneurship also influences economic development. To obviate concerns about endogeneity or reverse causality, we used lagged values of income per capita.

The evidence suggests that foreign direct investment (FDI) impacts on the entrepreneurial activity of a country (Ayyagari \& Kosová 2010; De Backer \& Sleuwaegen 2003). We therefore controlled for FDI as a percentage of GDP. We also included time-fixed effects to account for unobserved characteristics across years that might arise from missing variables (Wooldridge 2002).

\section{Statistical procedures}

We used multiple regression to test the significance of variance in cross-country entrepreneurship due to the twoway interaction term. The term was necessary to model the moderating effects of government policy support on the autonomy-entrepreneurship relationship.

Since we relied on eight years of secondary data, we applied panel analysis to the regressions. The data set consisted of unbalanced panel data, since only a few countries were present in the panel for all years. Levie and Autio (2008) recommend using the Baltagi-Wu test to check for autocorrelation of unbalanced panel data. They cite Kogel (2004), who suggests values that are much smaller than 2 are suggestive of a need to correct for serial autocorrelation. We obtained a test value of 1.7 and therefore ran generalised least squares (GLS) models, without controlling for autocorrelation in error terms.

We used the Hausman test to determine whether a fixedeffect or random-effect specification was appropriate for the 
TABLE 1: Descriptive statistics and correlations.

\begin{tabular}{|c|c|c|c|c|c|c|c|c|c|}
\hline Statistics & Mean & Standard deviation & 1 & 2 & 3 & 4 & 5 & 6 & 7 \\
\hline 1. Entrepreneurship & 4.41 & 4.19 & & & & & & & \\
\hline 2. Transition economy dummy & 0.13 & 0.34 & -0.12 & & & & & & \\
\hline 3. Foreign direct investment & 5.72 & 9.26 & 0.14 & -0.02 & & & & & \\
\hline 4. Population growth & 0.76 & 0.69 & $0.27 *$ & $-0.49 *$ & 0.04 & & & & \\
\hline 5. GDP per capita & 24463.60 & 16565.03 & $0.35 *$ & $-0.33 *$ & 0.09 & 0.10 & & & \\
\hline 6. Higher education & 2.80 & 0.32 & 0.11 & -0.12 & 0.14 & $0.27 *$ & $0.35 *$ & & \\
\hline 8. Government policy support & 2.65 & 0.52 & $0.17 *$ & $-0.32 *$ & $0.16 *$ & $0.17 *$ & $0.37 *$ & $0.16^{*}$ & 0.12 \\
\hline
\end{tabular}

Transition 1, no transition 0 .

$*, p<5 \%$

GLS panel regression. This test assesses correlation between residuals of pooled least squares and independent variables. The test suggested use of random-effects specification. To control for potential heteroscedasticity in error terms arising from grouping by country, we specified robust standard errors when running models.

We tested interaction by observing the significance of its contribution beyond effects from lower-order terms (Cohen et al. 2003). We conducted incremental Wald tests (Calvo 2006; Chou \& Bentler 1990) to determine whether these contributions were significant.

The significance of the two-way interaction signalled the importance of proceeding to examine the nature of the interaction. One begins by examining the sign of the main effects and interaction term. A synergistic or enhancing interaction occurs when both main effects and interaction effects are the same sign, indicating they influenced entrepreneurship in the same direction. In comparison, when one variable buffers or weakens the effect of the other, the main effect terms have opposite signs. When both main effects have the same sign but the higher-order interaction term has a different sign (Neter, Wasserman \& Kutner 1996), an either-or pattern of influence is concluded - one predictor compensates for the other (Cohen et al. 2003). In essence, the importance of one predictor is lessened by the importance of the existence or level of another. Thereafter, we used simple slope analysis (Dawson \& Richter 2006) to examine the autonomy-entrepreneurship relationship based on the contingent effect of government policy support.

\section{Results}

The mean values of government policy support and autonomy indicate no dominant features in the sample (see Table 1). The mean GDP per capita value of the sample, 24 463.60, is equivalent to a country like Cyprus. There are no extremely high correlations, typically greater than 0.70 , between independent variables. For a small sample and low t-values, variance inflation factor (VIF) values well below 5 are appropriate (Allison 2012; O'Brien 2007). We obtained VIF values below 3 for our models. Nevertheless, following Cohen et al.'s (2003) advice for dealing with regressions, including interaction terms, we centred all variables.
TABLE 2: Regression models (robust standard errors and centred variables).

\begin{tabular}{lcc}
\hline Entrepreneurship & $\begin{array}{c}\text { Model 1 } \\
\boldsymbol{\beta} \text { (standard error) }\end{array}$ & $\begin{array}{c}\text { Model 2 } \\
\boldsymbol{\beta} \text { (standard error) }\end{array}$ \\
\hline Constant & $4.70^{* *}(0.87)$ & $4.63^{* *}(0.87)$ \\
Transition dummies & $1.69(1.48)$ & $2.37+(1.27)$ \\
Foreign direct investment & $0.05^{* *}(0.02)$ & $0.06 * *(0.02)$ \\
Population growth & $0.58^{*}(0.23)$ & $0.66^{* *}(0.24)$ \\
GDP per capita (lagged) & $0.00^{* *}(0.00)$ & $0.00 * *(0.00)$ \\
Higher education EFC & $0.90(0.75)$ & $0.79(0.69)$ \\
Autonomy & $0.41(0.62)$ & $0.55(0.64)$ \\
Government policy support & $-0.50(0.68)$ & $-0.56(0.62)$ \\
Autonomy x Government policy support & - & $-2.21 *(1.02)$ \\
$R$-squared (within) & 0.40 & 0.45 \\
Chi-squared statistic (df) & $233.86(13)$ & $181.55(14)$ \\
Wald test (df) & - & $4.72 *(1)$ \\
Observations & 118 & 118 \\
Groups & 32 & 32 \\
\hline
\end{tabular}

Note: Year effects controlled for but not shown.

$+10 \% ; *, p<5 \% ; * *, p<1 \%$

Model 2 (see Table 2) shows that the interaction term is significant and lends support to our hypothesis that government policy support moderates the autonomyentrepreneurship relationship. The coefficient for the interaction term was negative $(B=-2.21, p<5 \%)$, with opposite signs for the main effect terms. Earlier, we noted that this type of model indicates a situation where one variable buffers or weakens the effect of the other (Neter, Wasserman \& Kutner 1996). This lends further support to our hypothesis that autonomy has a positive effect on entrepreneurship only when the level of government policy support is low.

To understand the interaction effect of autonomy and government policy support better, we graphed the effect of autonomy on entrepreneurship at low (1 SD below the mean) and high levels of government policy support (1 SD above the mean). Figure 2 confirms the findings demonstrated by observing the signs of the coefficients. Again, the effect of autonomy on entrepreneurship is positive at lower levels of government policy support.

\section{Discussion and conclusion}

We set out to test our argument that high levels of government policy support for new and growing enterprises crowd out the population's need for autonomy when potential entrepreneurs perceive government to be controlling. These members of the population might therefore remain in paid employment and the respective countries will enjoy lower 


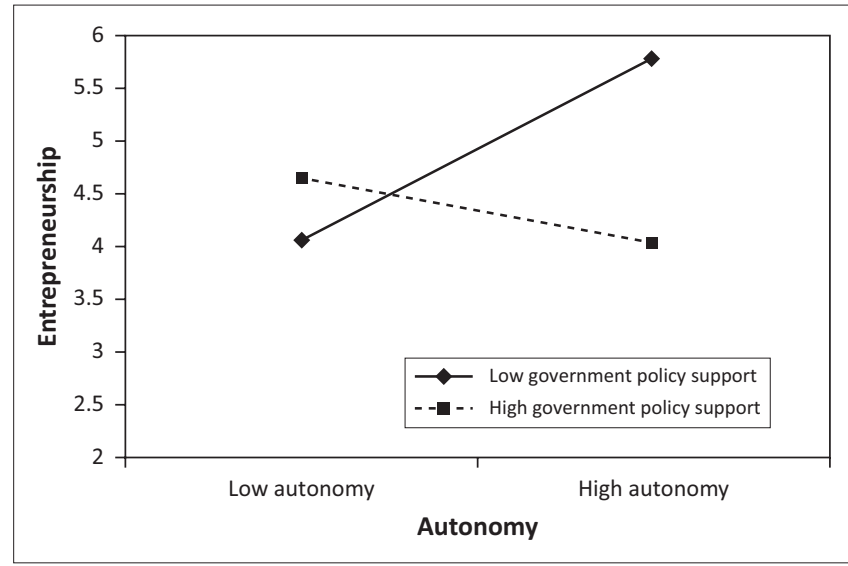

FIGURE 2: Moderating effect of government policy support on the autonomyentrepreneurship relationship.

entrepreneurship levels than government had anticipated. Our findings show that government policy support tends to buffer the effect of autonomy on entrepreneurship lending support to our argument. In the language of Frey and Jegen (2001:3), high levels of government policy support 'crowd out' the need for autonomy. When government policy support for new and growing enterprises is at a low level, the crowding out effect is absent and population-level autonomy can serve as a key driver of entrepreneurship.

Our measure of government policy support emphasised new and growing businesses. This emphasis of government policy support on new and growing enterprises do not often align with the goals of those populations who seek autonomy and lifestyle benefits and therefore might not prioritise growth and wealth creation. When taken too far to control entrepreneurship outcomes, government policy support can be harmful to those countries requiring high entrepreneurship levels to boost their economic growth. We thus get to test one of the most important anomalies in economics on entrepreneurship: that this 'crowding out' might reverse the most fundamental economic law, namely that raising economic incentives increases the supply of entrepreneurship (Frey \& Jegen 2001).

Our findings confirm other research (Albert \& Couture 2013) in which support initiatives led to a decrease in values such as autonomy and developed dependence amongst entrepreneurs. Self-determination theory (Deci \& Ryan 1985) suggests that entrepreneurs value their autonomy to such an extent that they are prepared to risk their own resources and even incur reduced incomes from new venture creation in order to enjoy its accompanying freedom and independence (Croson \& Minniti 2012). However, this scenario is less likely when high levels of government policy support are targeted towards growing enterprises - where resources are generously deployed to support the entrepreneur. High levels of government support reduce the risk of the individual lowering their income when moving from paid employment to entrepreneurship, making it less likely that one needs to trade in wealth for autonomy. In fact, an intrinsic desire for autonomy might even be substituted by extrinsic monetary incentives (Frey 1998) made possible by government support, for example captive revenue generated from government's preferential procurement from new enterprises. Potential entrepreneurs then take less responsibility for motivating themselves, with the outcome of entrepreneurial commitment that does not last over the longer term.

It is necessary to point out that this crowding-out effect occurs under certain circumstances. Self-determination theory suggests high levels of autonomy for those who also take pride in being competent (Ryan \& Deci 2000). It is likely then that the crowding-out effect of policy support applies to entrepreneurship involving a high level of task complexity. This might include innovative activity, where high levels of technology and skills are utilised in the operations of an enterprise. Government policy support is unlikely to crowd out autonomy for less complex entrepreneurial activity such as general retail activity or the corner shop down the street. We must also acknowledge that this theory is likely to hold more in developed countries, where material needs are likely to have been satisfied and the need for self-realisation takes over, than in developing countries (Uhlaner \& Thurik 2007). Amongst developing countries, we expect high levels of government support to continue to be important to spur on entrepreneurship.

Our research contains some limitations. We used the opinions of country experts. Although results are intuitively appealing, various patterns might be observed when using longitudinal, individual-level data. Hard country-level data is also necessary to test the validity of GEM EFCs (Levie \& Autio 2008). We recommend that researchers replicate this study with a sample of individual entrepreneurs. Whilst we tested our theory by using autonomy, passion for one's work is also an important intrinsic motivator (Cardon et al. 2009). We recommend that our line of research be extended using measures of passion for one's work.

We extracted data for entrepreneurship from the WBGES database regarding new business registrations worldwide, limiting application to formal economies (Acs et al. 2008; Klapper \& Delgado 2007). We recommend that our line of research be extended using broader measures entrepreneurship accounting for both necessity and opportunity motivation of entrepreneurship, for example the GEM total entrepreneurial activity data set.

Finally, our research suggests that governments, especially those in developed countries, must consider the crowdingout effects of policy support tools like subsidies and preferential procurement, especially when they do not screen enterprises carefully for their capacity to produce products and services (Shane 2008). To crowd in the need for autonomy, governments might design education policy to shape normative beliefs of younger generations, with earlier exposure to entrepreneurial concepts and successes and inclusion of entrepreneurship in elementary through 
post-secondary curricula. Another policy tool is social norms marketing campaigns, which use diverse media and samplebased data to shift people's perceptions of how society views these options (Valdez \& Richardson 2013). All in all, screening for non-pecuniary motivators like autonomy, freedom, creativity, lifestyle and doing what one loves deserves more explicit attention instead of the stereotypical monetary benefits.

\section{Acknowledgements Competing interests}

The authors declare that they have no financial or personal relationships that may have inappropriately influenced them in writing this article.

\section{Authors' contributions}

C.R. (University of Johannesburg), R.H. (University of Cape Town) and B.U. (University of Witwatersrand) designed the study and wrote the manuscript. C.R. collected and analysed the data.

\section{References}

Acs, Z.J., Desai, S. \& Hessels, J., 2008, 'Entrepreneurship, economic development and institutions', Small Business Economics 31(3), 219-234. http://dx.doi. org/10.1007/s11187-008-9135-9

Acs, Z.J., Desai, S. \& Klapper, L.F., 2008, 'What does 'entrepreneurship' data really show?', Small Business Economics 31(3), 265-281. http://dx.doi.org/10.1007/ s11187-008-9137-7

Aguilar, A.C., García Muñoz, T.M. \& Moro-Egido, A.l., 2013, 'Heterogeneous selfemployment and satisfaction in Latin America', Journal of Economic Psychology 39, 44-61. http://dx.doi.org/10.1016/j.joep.2013.07.001

Albert, M.N. \& Couture, M.M., 2013, 'The support to an entrepreneur from autonomy to dependence', SAGE Open 3(2), 1-9. http://dx.doi. org/10.1177/2158244013492779

Allison, P.D., 2012, Logistic regression using SAS: Theory and application, SAS Institute, Cary, NC.

Ayyagari, M. \& Kosová, R., 2010, 'Does FDI facilitate domestic entry? Evidence from the Czech Republic', Review of International Economics 18(1), 14-29. http:// dx.doi.org/10.1111/j.1467-9396.2009.00854.x

Bhaduri, S. \& Kumar, H., 2011, 'Extrinsic and intrinsic motivations to innovate: Tracin the motivation of "grassroot" innovators in India', Mind \& Society 10(1), 27-55. http://dx.doi.org/10.1007/s11299-010-0081-2

Bowen, H.P. \& De Clercq, D., 2008, 'Institutional context and the allocation of entrepreneurial effort', Journal of International Business Studies 39(4), 747-767. http://dx.doi.org/10.1057/palgrave.jibs.8400343

Bradley, D.E. \& Roberts, J.A., 2004, 'Self-employment and job satisfaction: Investigating the role of self-efficacy, depression and seniority', Journal of Small Business Management 42, 37-58. http://dx.doi.org/10.1111/j.1540-627X.2004.00096.x

Breaugh, J.A., 1999, 'Further investigation of the work autonomy scales: Two studies', Journal of Business and Psychology 13(3), 357-373. http://dx.doi. org/10.1023/A:1022926416628

Caliendo, M. \& Kritikos, A., 2012, 'Searching for the entrepreneurial personality: New evidence and avenues for further research', Journal of Economic Psychology 33(2) 319-324. http://dx.doi.org/10.1016/j.joep.2011.06.001

Calvo, J.L., 2006, 'Testing Gibrat's law for small, young and innovating firms', Small Business Economics 26(2), 117-123. http://dx.doi.org/10.1007/s11187-004 2135-5

Cardon, M.S., Wincent, J., Singh, J. \& Drnovsek, M., 2009, 'The nature and experience of entrepreneurial passion', Academy of Management Review 34(3), 511-532. http://dx.doi.org/10.5465/AMR.2009.40633190

Carsrud, A. \& Brännback, M., 2011, 'Entrepreneurial motivations: What do we still need to know?', Journal of Small Business Management 49(1), 9-26. http://dx.doi. org/10.1111/j.1540-627X.2010.00312.x

Carsrud, A., Brännback, M., Elfving, J. \& Brandt, K., 2009, 'Motivations: The entrepreneurial mind and behavior', in A. Carsrud \& M. Brännback (eds.) Understanding the entrepreneurial mind: Opening the black box, pp. 141-166, Springer, London. http://dx.doi.org/10.1007/978-1-4419-0443-0_7

Carter, S., 2011, 'The rewards of entrepreneurship: Exploring the incomes, wealth, and economic well-being of entrepreneurial households', Entrepreneurship Theory and Practice 35(1), 39-55. http://dx.doi.org/10.1111/j.1540-6520.2010.00422.x
Carter, N.M., Gartner, W.B., Shaver, K.G. \& Gatewood, E.J., 2003, 'The career reasons of nascent entrepreneurs', Journal of Business Venturing 18(1), 13-39. http:// dx.doi.org/10.1016/S0883-9026(02)00078-2

Chou, C.P. \& Bentler, P.M., 1990, 'Model modification in covariance structure modeling: A comparison among likelihood ratio, Lagrange multiplier, and Wald tests', Multivariate Behavioral Research 25(1), 115-136. http://dx.doi. org/10.1207/s15327906mbr2501_13

Cohen, J., Cohen, P., West, S. \& Aiken, L., 2003, Applied multiple regression/correlation analysis for the behavioral sciences, L. Erlbaum Associates, Mahwah, NJ.

Croson, D.C. \& Minniti, M., 2012, 'Slipping the surly bonds: The value of autonomy in self-employment', Journal of Economic Psychology 33(2), 355-365. http://dx.doi. org/10.1016/j.joep.2011.05.001

Csikszentmihalyi, M. \& Rathunde, K., 1992, 'The measurement of flow in everyday life: Toward a theory of emergent motivation', in J.E. Jacobs (ed.), Nebraska Symposium on Motivation, pp. 57-97, University of Nebraska Press, Lincoln, NE.

Danziger, N. \& Valency, R., 2006, 'Career anchors: Distribution and impact on job satisfaction, the Israeli case', Career Development International 11(4), 293-303. $\mathrm{http}: / / \mathrm{dx}$.doi.org/10.1108/13620430610672513

Davidsson, P., 1995, 'Culture, structure and regional levels of entrepreneurship', Entrepreneurship \& Regional Development 7(1), 41-62. http://dx.doi. Entrepreneurship \& Regional
org/10.1080/08985629500000003

Dawson, J. \& Richter, A., 2006, 'Probing three-way interactions in moderated multiple regression: Development and application of a slope difference test', Journal of Applied Psychology 91(4), 917-926. http://dx.doi.org/10.1037/00219010.91.4.917

De Backer, K. \& Sleuwaegen, L., 2003, 'Does foreign direct investment crowd out domestic entrepreneurship?', Review of Industrial Organization 22(1), 67-84. http://dx.doi.org/10.1023/A:1022180317898

De Clercq, D., Lim D.S.K. \& Oh, C.H., 2011, 'Individual-level resources and new business activity: The contingent role of institutional context', Entrepreneurship Theory and Practice 37(2), 303-330. http://dx.doi.org/10.1111/j.1540-6520.2011.00470.x

Deci, E.L., 1971, 'Effects of externally mediated rewards on intrinsic motivation', Journal of Personality and Social Psychology 18(1), 105-115. http://dx.doi org/10.1037/h0030644

Deci, E.L. \& Flaste, R., 1995, Why we do what we do. The dynamics of personal autonomy, Grosset/Putnam, New York.

Deci, E.L. \& Ryan, R.M., 1985, Self-determination, Wiley Online Library, Hoboken, NJ.

Feldman, D.C. \& Bolino, M.C., 2000, 'Career patterns of the self-employed: Career motivations and career outcomes', Journal of Small Business Management 38(3), 53-68.

Frey, B.S., 1992, 'Tertium datur: Pricing, regulation and intrinsic motivation', Kyklos 45(2), 161-184. http://dx.doi.org/10.1111/j.1467-6435.1992.tb02112.x

Frey, B.S., 1997, Not just for the money: An economic theory of personal motivation, Edward Elgar Publishing, Cheltenham.

Frey, B.S., 1998, 'Institutions and morale: The crowding-out effect', in A. Ben-Ner \& L.G. Putterman (eds.), Economics, Values, and Organization, pp. 437-460, Cambridge University Press, Cambridge. http://dx.doi.org/10.1017/CBO9781139174855.019

Frey, B.S. \& Jegen, R., 2001, 'Motivation crowding theory', Journal of Economic Surveys 15(5), 589-611. http://dx.doi.org/10.1111/1467-6419.00150

Gartner, W.B., 1985, 'A conceptual framework for describing the phenomenon of new venture creation', Academy of Management Review 10(4), 696-706.

Hoffman, A., 2007, 'A rough guide to entrepreneurship policy', in D.B. Audretsch, I. Grilo \& A.R. Thurik (eds.), Handbook of Research on Entrepreneurship Policy, pp. 94-129, Edward Elgar Publishing, Cheltenham. http://dx.doi. org/10.4337/9781847206794.00012

Keuschnigg, C. \& Nielsen, S.B., 2003, 'Tax policy, venture capital, and entrepreneurship', Journal of Public Economics 87(1), 175-203. http://dx.doi.org/10.1016/S00472727(01)00170-0

Klapper, L. \& Delgado, J.M., 2007, 'World Bank Group entrepreneurship survey: Data overview', in 2007 Kauffman Symposium on Entrepreneurship and Innovation Data, World Bank, Washington, DC.

Kogel, T., 2004, 'Did the association between fertility and female employment within OECD countries really change its sign?', Journal of Population Economics 17 45-65. http://dx.doi.org/10.1007/s00148-003-0180-z

Kolvereid, L., 1996, 'Organizational employment versus self-employment: Reasons for career choice intentions', Entrepreneurship Theory and Practice 20, 23-31.

Kuratko, D.F., Hornsby, J.S. \& Naffziger, D.W., 1997, 'An examination of owner's goals in sustaining entrepreneurship', Journal of Small Business Management 35(1), 24-33.

Laffont, J.J. \& Tirole, J., 1993, A theory of incentives in procurement and regulation, MIT Press, Cambridge, MA.

Leibenstein, H., 1968, 'Entrepreneurship and development', The American Economic Review 58(2), 72-83.

Levie, J. \& Autio, E., 2008, 'A theoretical grounding and test of the GEM model', Small Business Economics 31(3), 235-263. http://dx.doi.org/10.1007/s11187-0089136-8

Levie, J. \& Autio, E., 2011, 'Regulatory burden, rule of law, and entry of strategic entrepreneurs: An international panel study', Journal of Management Studies 48(6), 1392-1419. http://dx.doi.org/10.1111/j.1467-6486.2010.01006.x

McCrae, R.R. \& Terracciano, A., 2005, 'Personality profiles of cultures: Aggregate personality traits', Journal of Personality and Social Psychology 89(3), 407-425. http://dx.doi.org/10.1037/0022-3514.89.3.407 
Neter, J., Wasserman, W. \& Kutner, M.H., 1996, Applied linear statistical models, Irwin Chicago, IL.

North, D.C., 1990, Institutions, institutional change and economic performance, Cambridge University Press, Cambridge. http://dx.doi.org/10.1017/ CBO9780511808678

O'Brien, R.M., 2007, 'A caution regarding rules of thumb for variance inflation factors', Quality and Quantity 41(5), 673-690. http://dx.doi.org/10.1007/s11135-0069018-6

OECD, 1997, The OECD report of regulatory reform, OECD, Paris, France.

Ryan, R.M. \& Deci, E.L., 2000, 'Self-determination theory and the facilitation of intrinsic motivation, social development, and well-being', American Psychologist 55(1), 68-78. http://dx.doi.org/10.1037/0003-066X.55.1.68

Schjoedt, L., 2009, 'Entrepreneurial job characteristics: An examination of their effects on entrepreneurial satisfaction', Entrepreneurship Theory and Practice 33(3), 619-644. http://dx.doi.org/10.1111/j.1540-6520.2009.00319.x

Shane, S., 1993, 'Cultural influences on national rates of innovation', Journal of Business Venturing 8(1), 59-73. http://dx.doi.org/10.1016/0883-9026(93) 90011-S

Shane, S., 2008, The illusions of entrepreneurship, Yale University Press, New Haven, CT.
Uhlaner, L. \& Thurik, R., 2007, 'Postmaterialism influencing total entrepreneurial activity across nations', Journal of Evolutionary Economics 17(2), 161-185. http:// dx.doi.org/10.1007/s00191-006-0046-0

Valdez, M.E. \& Richardson, J., 2013, 'Institutional determinants of macro-level entrepreneurship', Entrepreneurship Theory and Practice 37(5), 1149-1175. http://dx.doi.org/10.1111/etap.12000

Van Stel, A., Carree, M. \& Thurik, R., 2005, 'The effect of entrepreneurial activity on national economic growth', Small Business Economics 24(3), 311-321. http:// dx.doi.org/10.1007/s11187-005-1996-6

Wennekers, A.R.M., 2006, Entrepreneurship at country level: Economic and noneconomic determinants, Erasmus University, Rotterdam, The Netherlands.

Wennekers, S. \& Thurik, R., 1999, 'Linking entrepreneurship and economic growth', Small Business Economics 13(1), 27-56. http://dx.doi.org/10.1023/ A: 1008063200484

Wennekers, S., Van Wennekers, A., Thurik, R. \& Reynolds, P., 2005, 'Nascent entrepreneurship and the level of economic development', Small Business Economics 24(3), 293-309. http://dx.doi.org/10.1007/s11187-005-1994-8

Wooldridge, J.M., 2002, Econometric analysis of cross section and panel data, MIT Press, Cambridge, MA. 